\title{
WPLYW ROZSZERZALNOŚCI CIEPLNEJ NA WSPÓŁCZYNNIK NIERÓWNOMIERNOŚCI ROZKŁADU OBCIĄŻENIA WZDŁUŻ LINII STYKU
}

\begin{abstract}
W artykule przedstawiono wyniki obliczeń numerycznych wpływu rozszerzalności cieplnej korpusu i podzespołów dwustopniowej przekładni zębatej walcowej na współczynnik nierównomierności rozkładu obciążenia wzdłuż linii styku KHß. Analizę przeprowadzono na przykładzie przekładni zębatej będącej częścią głównego układu napędowego siłowni okrętowej. W obliczeniach wykorzystano metodę iteracyjnego wyznaczania rozkładu obciążenia wzdłuż linii styku opisanej w normie ISO 6336-1 załącznik E. Wykazano przydatność implementacji metody iteracyjnej wewnątrz środowiska programu CAE oraz łatwość jej rozbudowy o dodatkowe czynniki i zjawiska zwiększające dokładność obliczeń. Uzyskane wyniki pozwalają na ocenę wpływu zjawiska rozszerzalności cieplnej oraz zasadności jej uwzględnienia na etapie projektowania modyfikacji linii zęba przekładni zębatej siłowni okrętowej.
\end{abstract}

Słowa kluczowe: współczynnik $\mathrm{K}_{\mathrm{H} \beta}$, siłownia okrętowa, przekładnia zębata, odchyłka linii styku

\section{Wstęp}

W wyniku odchyłek wykonawczych i odkształceń wszystkich elementów nośnych przekładni zębatej całkowita siła obwodowa zazwyczaj nie rozkłada się równomiernie wzdłuż linii styku. Zależnie od obciążenia, sztywności i odchyłek wykonawczych boki zęba mogą przenosić obciążenie na całej szerokości lub tylko na pewnej jej części. Przy obliczaniu naprężeń nominalnych przyjmuje się, że obciążenia i naprężenia rozkładają się równomiernie wzdłuż linii styku. Dla wytrzymałości zęba miarodajne są maksymalne wartości naprężeń, jakie występują na szerokości wieńca. Aby sprawdzanie wytrzymałości oprzeć na maksymalnych naprężeniach wprowadza się do obliczeń współczynniki nierównomiernego rozkładu obciążenia wzdłuż linii styku [10]. Czynnikami, które

\footnotetext{
${ }^{1}$ Wojciech Kucab, e-mail: wojciechkcab@ gmail.com

2 Autor do korespondencji/corresponding author: Adam Marciniec, Politechnika Rzeszowska, al. Powstańców Warszawy 8, 35-959 Rzeszów, tel. +48 17865 1415, email: amarc@ prz.edu.pl
} 
w największym stopniu bezpośrednio wpływają na rozkład obciążenia wzdłuż linii styku są odkształcenia giętne i skrętne wałów (rys. 1).

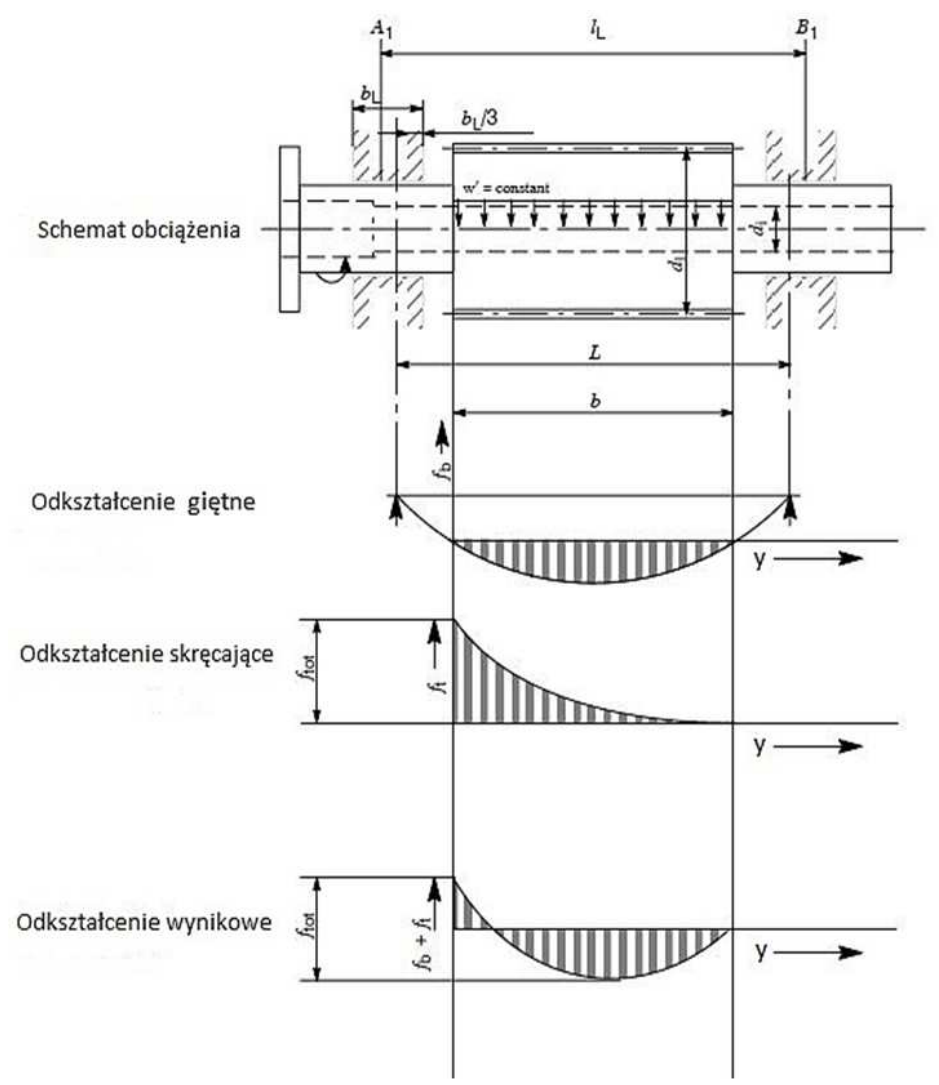

Rys. 1. Odkształcenie giętne i skrętne wału

Fig.1. Transverse and torsional deformations of shaft

Kolejnym z czynników, który decyduje o rozkładzie obciążenia wzdłuż linii styku jest rozszerzalność cieplna. Rozszerzalność cieplna wałów, łożysk i korpusu skutkuje zmianą luzu roboczego łożysk oraz ich przemieszczeniem względem pozycji bazowej. Wszystko to wpływa na kształt i wielkość linii ugięcia wału a przez to w sposób pośredni na rozkład obciążenia wzdłuż linii styku. Zjawiskiem cieplnym, które w sposób bezpośredni wpływa na rozkład obciążenia jest nierównomierny wzrost temperatury wzdłuż linii zęba. Zjawisko to staje się znaczące i należy go uwzględnić podczas obliczania modyfikacji powierzchni zęba dla przekładni szybkoobrotowych dużych mocy, gdzie prędkość obwodowa kół przekracza $90 \mathrm{~m} / \mathrm{s}$ [12]. Ze względu na to, że maksymalna prędkość obwodowa badanej przekładni na stopniu I wynosi $21,6 \mathrm{~m} / \mathrm{s}$ zjawisko to zostało uznane za nieistotne i nie zostało dalej omówione. 
Źródłem ciepła generowanego w przekładni jest moc tracona na skutek tarcia międzyzębnego, w łożyskach, uszczelnień na wale oraz rozbryzgiwania oleju. Wynikiem produkowanego ciepła jest wzrost temperatury członów przekładni oraz środka smarnego. Istnieją dwa międzynarodowe raporty techniczne [6, 7], na podstawie których można oszacować straty powstałe w przekładni. Pierwszy z nich to ISO/TR 14179-1, który jest propozycją Amerykańskiego Stowarzyszenia Producentów Przekładni (AGMA). Wykorzystuje on analityczny model bilansu cieplnego w celu wyznaczenia maksymalnej mocy cieplnej jaka może zostać wygenerowana w przekładni bez przekroczenia dopuszczalnej temperatury oleju w misce olejowej. Drugi raport ISO TR 14179-2 jest propozycją niemiecką, gdzie obliczany jest stan równowagi cieplnej między mocą traconą a ciepłem rozpraszanym. Zależnie od wybranej metody temperatura pracy przekładni może być określona eksperymentalnie (metoda amerykańska) lub analitycznie (metoda niemiecka).

\section{Model przekładni zębatej}

Analizę wykonano dla przekładni walcowej dwustopniowej o zębach skośnych będącej częścią głównego napędu siłowni okrętowej.

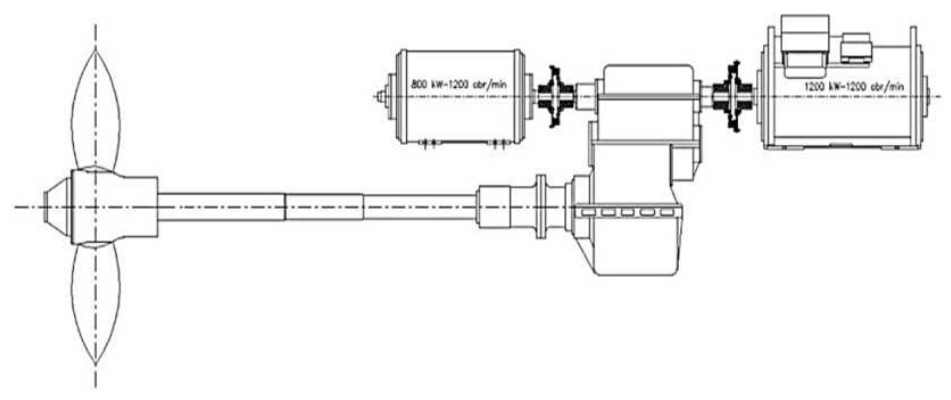

Rys.2. Główny układ napędowy siłowni okrętowej

Fig. 2. Main power transmission system of marine power plant

Sumaryczna nominalna moc przenoszona przez przekładnię wynosi $2000 \mathrm{~kW}$, pochodzi ona z dwóch silników elektrycznych sterowanych falownikiem połączonych wałem wejściowym (rys. 2). Źródłem energii elektrycznej statku są trzy generatory diesla. Konstrukcja przekładni została pokazana na rysunku 3 i 4. Dane techniczne przekładni oraz geometrię uzębienia przedstawiono w tabeli 1 . 
Tabela 1. Parametry badanej przekładni

Table 1. Parameters of analysed gear

\begin{tabular}{|c|c|c|c|c|}
\hline \multicolumn{5}{|c|}{ Dane techniczne } \\
\hline & \multicolumn{2}{|c|}{ Silnik I } & \multicolumn{2}{|c|}{ Silnik II } \\
\hline Moc silnika $[\mathrm{kW}]$ & \multicolumn{2}{|c|}{1200} & \multicolumn{2}{|c|}{800} \\
\hline Prędkość obrotowa silnika [obr/min] & \multicolumn{4}{|c|}{1200} \\
\hline Kierunek obrotu silnika & \multicolumn{2}{|c|}{ Lewy } & \multicolumn{2}{|c|}{ Prawy } \\
\hline \multicolumn{5}{|c|}{ Geometria kół zębatych } \\
\hline & \multicolumn{2}{|c|}{ Stopień I } & \multicolumn{2}{|c|}{ Stopień II } \\
\hline & Zębnik & Koto & Zębnik & Koto \\
\hline Liczba zębów Z [mm] & 37 & 59 & 21 & 95 \\
\hline Moduł $\mathrm{m}_{\mathrm{n}}[\mathrm{mm}]$ & \multicolumn{2}{|c|}{9} & \multicolumn{2}{|c|}{10} \\
\hline Kąt zarysu $\alpha_{\mathrm{n}}\left[{ }^{\circ}\right]$ & \multicolumn{2}{|c|}{20} & \multicolumn{2}{|c|}{20} \\
\hline Kąt pochylenia linii zęba $\beta\left[^{\circ}\right]$ & \multicolumn{2}{|c|}{14} & \multicolumn{2}{|c|}{14} \\
\hline Kierunek pochylenia linii zęba & Lewy & Prawy & Lewy & Prawy \\
\hline Odległość osi a [mm] & \multicolumn{2}{|c|}{450} & \multicolumn{2}{|c|}{600} \\
\hline Szerokość wieńca b [mm] & \multicolumn{2}{|c|}{120} & 300 & 280 \\
\hline Współczynnik przesunięcia zarysu x* & 0.1100 & 0.4401 & 0.0810 & 0.1464 \\
\hline Klasa dokładności wykonania (ISO 1328) & \multicolumn{2}{|c|}{5} & \multicolumn{2}{|c|}{ J } \\
\hline Materiał & \multicolumn{2}{|c|}{ 18CrNiMo7-6 } & \multicolumn{2}{|c|}{$18 \mathrm{CrNiMo} 7-6$} \\
\hline
\end{tabular}

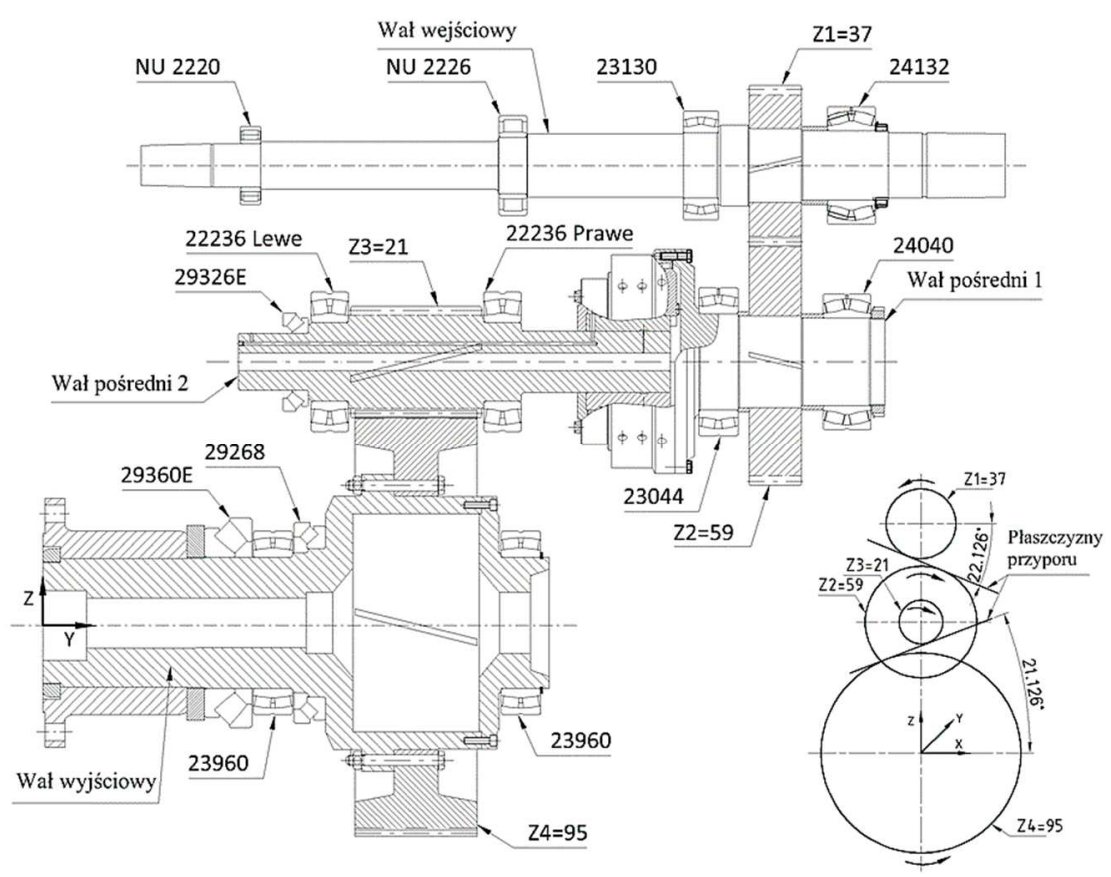

Rys. 3. Model przekładni wraz z opisem łożysk i wałów

Fig. 3. Gear model with specification of bearings and shafts 
Rys. 4. Model przekładni wykonany w środowisku programu KISSsys

Fig. 4. Gear model prepared in KISSsys software environment

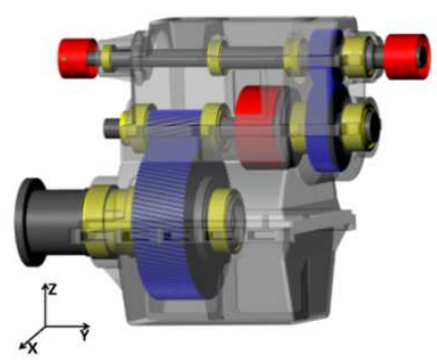

\section{Procedura obliczeniowa}

Normy ISO 6336-1 (metoda C) [9] i AGMA 2001 [2] podają uproszczone wzory na wyznaczenie współczynnika $\mathrm{K}_{\mathrm{H} \beta}$ oraz zakładają, że rozkład obciążenia ma postać prostoliniową. Uzyskane wyniki są zatem niezbyt dokładne i mało realistyczne. Według norm wyznaczenie rozkładu obciążenia odbywa się w dwóch krokach. Najpierw obliczana jest odchyłka linii styku a następnie uwzględniając sztywność zazębienia rozkład obciążenia.

Inne podejście, charakteryzujące się większą dokładnością, zostało po raz pierwszy przedstawione w normie AGMA 927-A01 [3], a następnie zaimplementowane w międzynarodowym standardzie ISO 6336-1 (2006) załącznik E. Według tej metody rozkład obciążenia wyznaczany jest iteracyjnie.

Zaproponowana metoda analityczna posiada kilka znaczących udoskonaleń w porównaniu do uproszczonej metody C. Pozwala ona na uwzględnienie odkształceń dwóch członów pary zębatej (zębnika i koła). Ząb wzdłuż jego szerokości dzielony jest na równe części, po czym wyznacza się pierwszą postać odkształcenia wałów przy założeniu równomiernego rozkładu obciążenia wzdłuż linii styku. Na podstawie uzyskanych odkształceń i wyjściowej odchyłki linii styku obliczany jest nierównomierny rozkład obciążenia. Nowy rozkład zostaje użyty do wyznaczenia nowej postaci odkształceń wałów. Pętla iteracyjna powtarzana jest aż do momentu uzyskania niewielkiej różnicy pomiędzy kolejnymi iteracjami. Zazwyczaj dwie lub trzy iteracje są wymagane do uzyskania zadowalającej dokładności obliczeń [1].

Wielkości odkształceń giętnych i skrętnych wałów w płaszczyźnie przyporu zostały obliczone przy użyciu komercyjnego programu komputerowego wspomagającego prace inżynierskie KISSsys. Uzyskane wartości zostały wyeksportowane i użyte do wyznaczenia odchyłki linii styku, co pozwala na obliczenie rozkładu obciążenia oraz współczynnika $\mathrm{K}_{\mathrm{H} \beta}$. W celu wyznaczenia odkształceń sprężystych i cieplnych korpusu przekładni wykorzystano metodę elementów skończonych.

Wykonano cztery analizy, które pozwoliły na oszacowanie wpływu zjawisk cieplnych na rozkład obciążenia wzdłuż linii styku. Pierwsza z nich jest analizą bazową do której będzie można odnieść wyniki pozostałych analiz. Analiza 
druga opisuje wpływ wzrostu temperatury w przekładni na zmianę luzu roboczego w łożyskach. Zmiana luzu roboczego wpływa na wielkość i kształt odkształceń wałów, a zatem również rozkład obciążenia wzdłuż linii styku. Analiza trzecia przedstawia działanie odkształceń sprężystych korpusu przekładni na rozkład obciążenia wzdłuż linii styku. Jest ona analizą pośrednią mającą na celu uzyskanie wyników, do których będzie można odnieść wyniki analizy czwartej. Analiza czwarta została przeprowadzona przy uwzględnieniu odkształceń cieplnych korpusu. Zarówno odkształcenia sprężyste korpusu pod działaniem sił łożyskowych jak i odkształcenia cieplne korpusu powodują przemieszczenie łożysk względem pozycji bazowej, co w sposób pośredni wpływa na odchyłkę linii styku a zatem również współczynnik $\mathrm{K}_{\mathrm{H} \beta}$. Porównanie analizy trzeciej z czwartą pozwoliło na ocenę rzeczywistego wpływu odkształceń cieplnych na rozkład obciążenia. Wyniki analiz przedstawiono w punkcie 4.

\subsection{Model bazowy}

W celu jak najdokładniejszego odwzorowania rzeczywistego stanu odkształceń walów w modelu bazowym uwzględniono:

- odkształcenia skrętne i giętne wałów,

- nierównomierny rozkład obciążenia wzdłuż linii styku (wzrost dokładności zapewniono metodą iteracyjną),

- masy komponentów (wałów, sprzęgieł, kół zębatych),

- odkształcenia sprężyste korpusów kół zębatych (metoda MES),

- wpływ usztywnienia wału spowodowany przez elementy na nim zamontowane (wg. ISO 6336-1),

- wpływ naprężeń ścinających na linię ugięcia wału (wg. teorii Timoshenko),

- luz łożyskowy i jego zmianę spowodowaną pasowaniem oraz założoną tolerancją,

- nieliniową sztywność łożysk, obliczoną wg. ISO/TR 16281 [8] na podstawie geometrii wewnętrznej łożyska,

- siły pochodzące od śruby okrętowej i osiowania wału.

\subsection{Analiza wpływu rozszerzalności cieplnej komponentów na luz roboczy łożysk}

Na skutek tarcia powstałego w zazębieniu, łożyskach i uszczelnieniach oraz generowanego w ten sposób ciepła następuje wzrost temperatury elementów przekładni względem temperatury otoczenia. W warunkach pracy ustalonej temperatura członów przekładni może różnić się w sposób znaczący. Wynika to $\mathrm{z}$ różnych warunków odprowadzania ciepła oraz chłodzenia przekładni w poszczególnych jej obszarach. Różnica temperatur wałów, łożysk oraz korpusu przy różnych współczynnikach rozszerzalności cieplnej powoduje zmianę luzu roboczego łożyska [13]. 
Ciepło powstałe na skutek tarcia całkowitego musi zostać odprowadzone, w ogólnym przypadku odbywa się to poprzez wał, korpus lub olej. Wielkość odprowadzanego przez korpus ciepła zależy od jego wielkości i warunków zewnętrznego chłodzenia. Ponieważ na wale mogą znajdować się inne źródła ciepła poza łożyskami kierunek przepływu ciepła nie zawsze musi odbywać się z łożyska na wał [14]. W obliczeniach przyjęto, że temperatura pierścienia zewnętrznego odpowiada temperaturze korpusu, a temperatura pierścienia wewnętrznego temperaturze wału. Temperatura elementów tocznych jest średnią temperatur pierścienia wewnętrznego i zewnętrznego. W większości przypadków temperatura pierścienia wewnętrznego jest wyższa niż temperatura pierścienia zewnętrznego, co zazwyczaj prowadzi do zmniejszenia luzu roboczego [11].

Na podstawie pomiarów temperatury przekładni o zbliżonej mocy i warunkach pracy do obliczeń przyjęto:

- temperatura wałów $=50^{\circ} \mathrm{C}$,

- temperatura elementów tocznych $=45^{\circ} \mathrm{C}$,

- temperatura korpusu $=40^{\circ} \mathrm{C}$,

- temperatura otoczenia $=20^{\circ} \mathrm{C}$,

- temperatura oleju $=50^{\circ} \mathrm{C}$.

Wartości te odpowiadają normalnym warunkom pracy przekładni głównej siłowni okrętowej, przy zachowaniu poprawnie pracującego systemu chłodzenia oleju. Zmiana luzu na skutek różnicy temperatur oraz wartości luzu roboczego łożysk przedstawiono $\mathrm{w}$ tabeli 2 . Zmiana luzu roboczego wpływa na kształt i wielkość linii ugięcia wałów, co z kolei w sposób bezpośredni decyduje o rozkładzie obciążenia wzdłuż linii styku.

Tabela 2. Luz wewnętrzny i roboczy łożysk

Table 2. Internal and operating bearing slackness

\begin{tabular}{|c|c|c|c|c|c|}
\hline Lp. & Łożysko & $\begin{array}{c}\text { Luz we- } \\
\text { wnętrzny } \\
\mathrm{r}[\mu \mathrm{m}]\end{array}$ & $\begin{array}{c}\text { Zmiana luzu spo- } \\
\text { wodowana paso- } \\
\text { waniem } \Delta \mathrm{r}_{\text {fit }}[\mu \mathrm{m}]\end{array}$ & $\begin{array}{c}\text { Zmiana luzu spowodowa- } \\
\text { na różnicą temperatur } \\
\Delta \mathrm{r}_{\text {temp }}[\mu \mathrm{m}]\end{array}$ & $\begin{array}{c}\text { Luz roboczy } \\
\mathrm{r}_{\mathrm{op} 2}[\mu \mathrm{m}]\end{array}$ \\
\hline 1 & NU 2220 & 92,500 & $-24,775$ & $-15,546$ & 52,179 \\
\hline 2 & NU 2226 & 122,500 & $-31,013$ & $-19,986$ & 71,501 \\
\hline 3 & 23130 & 140,000 & $-42,234$ & $-24,036$ & 73,730 \\
\hline 4 & 24132 & 140,000 & $-42,101$ & $-26,180$ & 71,719 \\
\hline 5 & 23044 & 180,000 & $-67,500$ & $-33,437$ & 79,063 \\
\hline 6 & 24040 & 165,000 & $-50,405$ & $-30,704$ & 83,891 \\
\hline 7 & 22236 Lewe & 150,000 & $-54,856$ & $-30,005$ & 65,139 \\
\hline 8 & 22236 Prawe & 150,000 & $-54,856$ & $-30,005$ & 65,139 \\
\hline 9 & 23960 Lewe & 235,000 & $-74,753$ & $-42,764$ & 117,483 \\
\hline 10 & 23960 Prawe & 235,000 & $-73,343$ & $-42,764$ & 118,893 \\
\hline
\end{tabular}




\subsection{Wpływ odkształcalności sprężystej korpusu na rozkład obciążenia wzdłuż linii styku}

Na skutek odkształcalności cieplnej i sprężystej korpusu pierścienie zewnętrzne łożysk ulegają przemieszczeniu, co w konsekwencji wpływa na linie ugięcia wałów i może mieć znaczenie przy doborze odpowiedniej modyfikacji linii zęba. W celu prawidłowej oceny rzeczywistego oddziaływania odkształceń cieplnych korpusu wykonano analizę pośrednią wpływu odkształceń sprężystych korpusu pod działaniem sił łożyskowych na rozkład obciążenia. Model korpusu zaimportowano do środowiska MES, w którym zdefiniowano warunki brzegowe oraz przyłożono siły pochodzące od łożysk. W centralnej pozycji opraw łożyskowych zdefiniowano punkt zdalny (Remote Point). Został on połączony z gniazdem opraw za pomocą elementów belkowych.

W zależności od budowy łożyska może ono generować siły promieniowe, osiowe oraz momenty sił działające na korpus. Siły promieniowe i osiowe przyłożone są bezpośrednio do gniazd opraw oraz powierzchni oporowych. Momenty sił modelowane są przez ich przyłożenie do punktu zdalnego. Wykorzystanie tej procedury rozszerzonej o kilka dodatkowych formuł w języku APDL umożliwia odczytanie przemieszczeń oraz obrotów geometrii powiązanej z punktem bazowym.

Tabela 3. Wartości przemieszczeń i obrotów łożysk na skutek odkształceń sprężystych korpusu Table 3. Values of displacements and rotations of bearings caused by housing elastic deformation

\begin{tabular}{|c|c|c|c|c|c|c|}
\hline \multirow{2}{*}{ Lp. } & \multirow{2}{*}{ Łożysko } & \multicolumn{3}{|c|}{ Przemieszczenie $[\mu \mathrm{m}]$} & \multicolumn{2}{c|}{ Obrót ["] } \\
\cline { 3 - 7 } & & $\mathrm{X}$ & $\mathrm{Y}$ & $\mathrm{Z}$ & $\mathrm{X}$ & $\mathrm{Z}$ \\
\hline 1 & NU 2220 & 66,4 & $-32,1$ & 43,4 & -34 & -5 \\
\hline 2 & NU 2226 & 49,7 & $-9,8$ & $-4,1$ & 2 & -17 \\
\hline 3 & 23130 & $-31,2$ & $-15,7$ & 1,8 & 0 & -17 \\
\hline 4 & 24132 & $-58,2$ & 1,8 & 8,9 & 1 & -1 \\
\hline 5 & 23044 & $-0,6$ & $-13,5$ & $-0,3$ & 2 & -7 \\
\hline 6 & 24040 & $-14,5$ & $-16,4$ & 5,6 & -8 & -5 \\
\hline 7 & $29326 \mathrm{E}$ & 57,8 & $-54,6$ & $-23,7$ & 53 & 3 \\
\hline 8 & 22236 Lewe & 56,9 & $-50,0$ & 4,6 & 53 & 16 \\
\hline 9 & 22236 Prawe & 50,4 & 4,6 & $-3,0$ & 13 & -2 \\
\hline 10 & $29360 \mathrm{E}$ & $-2,3$ & 139,8 & $-4,2$ & 5 & -4 \\
\hline 11 & 23960 Lewe & $-1,5$ & 140,6 & $-3,1$ & 5 & -4 \\
\hline 12 & 29268 & $-0,4$ & 139,5 & $-2,0$ & 5 & -4 \\
\hline 13 & 23960 Prawe & $-4,7$ & 11,3 & $-17,7$ & -28 & 10 \\
\hline
\end{tabular}

Znając przemieszczenia i obroty pierścieni zewnętrznych możemy uwzględnić ich wartości w obliczeniach wałów i łożysk. Wartości uzyskane w środowisku MES zostały zaimportowane do programu KISSsys, jako przemieszczenia i obroty pierścienia zewnętrznego. Skutkuje to zmianą względnego położenia łożysk, co z kolei decyduje o kształcie i wielkości linii ugięcia wałów. Model obliczeniowy składa się z korpusu wraz z zamontowanymi w nim pier- 
ścieniami zewnętrznymi, co pozwala na uwzględnienie usztywnienia gniazd opraw. W modelu zastosowano uproszczenia polegające na wyeliminowaniu połączeń śrubowych, detali geometrycznych oraz założeniu nieskończenie sztywnego posadowienia przekładni. Wartości przemieszczeń i obrotów łożysk przedstawiono w tabeli 3 .

\subsection{Wpływ odkształcalności cieplnej korpusu na rozkład obciążenia wzdłuż linii styku}

Analiza trzecia została rozbudowana o wymuszenie cieplne działające na korpus. Przyjęto wzrost temperatury względem temperatury otoczenia o $20^{\circ} \mathrm{C}$. Założono również równomierny rozkład temperatury na całej powierzchni korpusu, co stanowi duże uproszczenie w stosunku do warunków rzeczywistej pracy przekładni. Numeryczne wyznaczenie dokładnego rozkładu temperatury na powierzchni korpusu wymagałoby uwzględnienia wszystkich lokalnych źródeł ciepła powstającego w zazębieniu, łożyskach i uszczelnieniach. Znaczącą rolę $\mathrm{w}$ wymianie ciepła wewnątrz przekładni odgrywa również ruch czynnika smarującego. Tak rozbudowany model matematyczny wiąże się z wysokim stopniem złożoności obliczeń. W przypadku, gdy celem obliczeń jest wyłącznie wyznaczenie względnego przemieszczenia łożysk w korpusie wydaje się być zasadnym uproszczenie modelu o przyjęcie uśrednionej wartości temperatury korpusu [5]. Wartości przemieszczeń i obrotów pierścieni zewnętrznych łożysk przedstawiono w tabeli 4.

Tabela 4. Wartości przemieszczeń i obrotów łożysk na skutek odkształcalności sprężystej i cieplnej korpusu

Table 4. Values of displacements and rotations of bearings caused by elastic and thermal deformations of frame

\begin{tabular}{|c|c|c|c|c|c|c|}
\hline \multirow{2}{*}{ Lp. } & \multirow{2}{*}{ Łożysko } & \multicolumn{3}{|c|}{ Przemieszczenie $[\mu \mathrm{m}]$} & \multicolumn{2}{c|}{ Obrót ["] } \\
\cline { 3 - 7 } & & $\mathrm{X}$ & $\mathrm{Y}$ & $\mathrm{Z}$ & $\mathrm{X}$ & $\mathrm{Z}$ \\
\hline 1 & NU 2220 & 66,3 & $-160,4$ & 384,3 & -41 & -5 \\
\hline 2 & NU 2226 & 49,8 & 6,0 & 323,5 & -4 & -17 \\
\hline 3 & 23130 & $-31,2$ & 104,2 & 316,8 & -6 & -17 \\
\hline 4 & 24132 & $-58,9$ & 205,4 & 312,5 & -4 & -1 \\
\hline 5 & 23044 & $-0,6$ & 105,2 & 207,4 & 0 & -7 \\
\hline 6 & 24040 & $-14,5$ & 171,2 & 200,8 & -14 & -5 \\
\hline 7 & $29326 \mathrm{E}$ & 57,8 & $-148,2$ & 189,4 & $124 "$ & 3 \\
\hline 8 & 22236 Lewe & 56,9 & $-118,9$ & 235,3 & $126 "$ & 1 \\
\hline 9 & 22236 Prawe & 50,3 & $-5,1$ & 223,3 & 4 & -2 \\
\hline 10 & $29360 \mathrm{E}$ & $-2,2$ & 87,9 & $-55,0$ & -20 & -4 \\
\hline 11 & 23960 Lewe & $-1,5$ & 100,0 & 49,6 & -20 & -4 \\
\hline 12 & 29268 & $-0,4$ & 111,0 & 44,1 & -20 & -4 \\
\hline 13 & 23960 Prawe & $-4,7$ & 1,1 & 11,0 & -18 & 10 \\
\hline
\end{tabular}




\section{Omówienie wyników}

W celu przeprowadzenia analizy porównawczej uzyskanych wyników sporządzono wykresy odkształceń giętnych linii wałów przekładni w płaszczyźnie przyporu (rys. 5) oraz wykresy wypadkowej odchyłki linii styku dwóch analizowanych par zębatych (rys. 6).
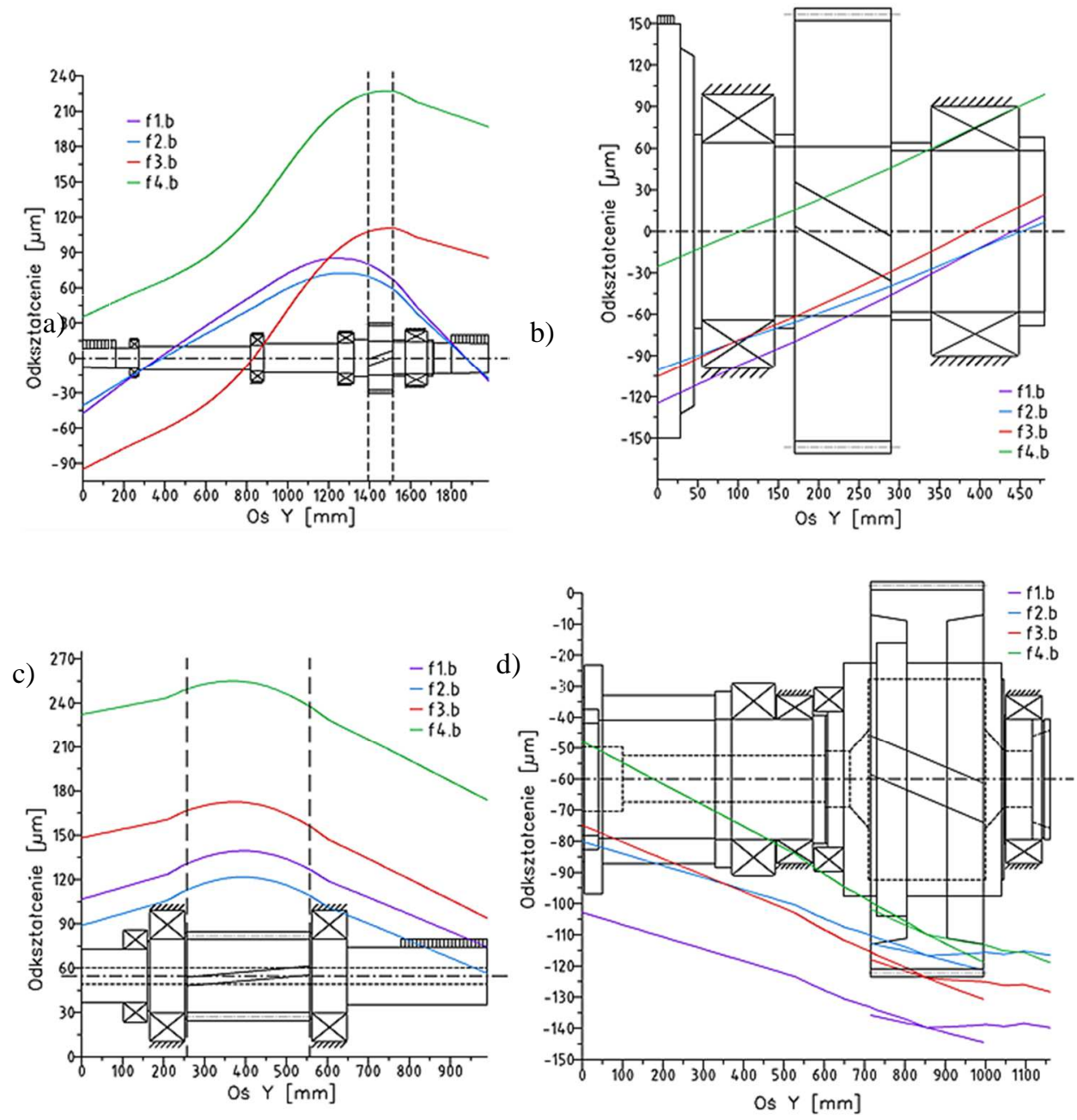

Rys. 5. Linia ugięcia w płaszczyźnie przyporu: a) wału wejściowego, b) wału pośredniego 1, c) wału pośredniego 2 , d) wału wyjściowego

Fig. 5. Bending line in plane of action: a) input shaft, b) countershaft 1 , c) countershaft 2 , d) output shaft 

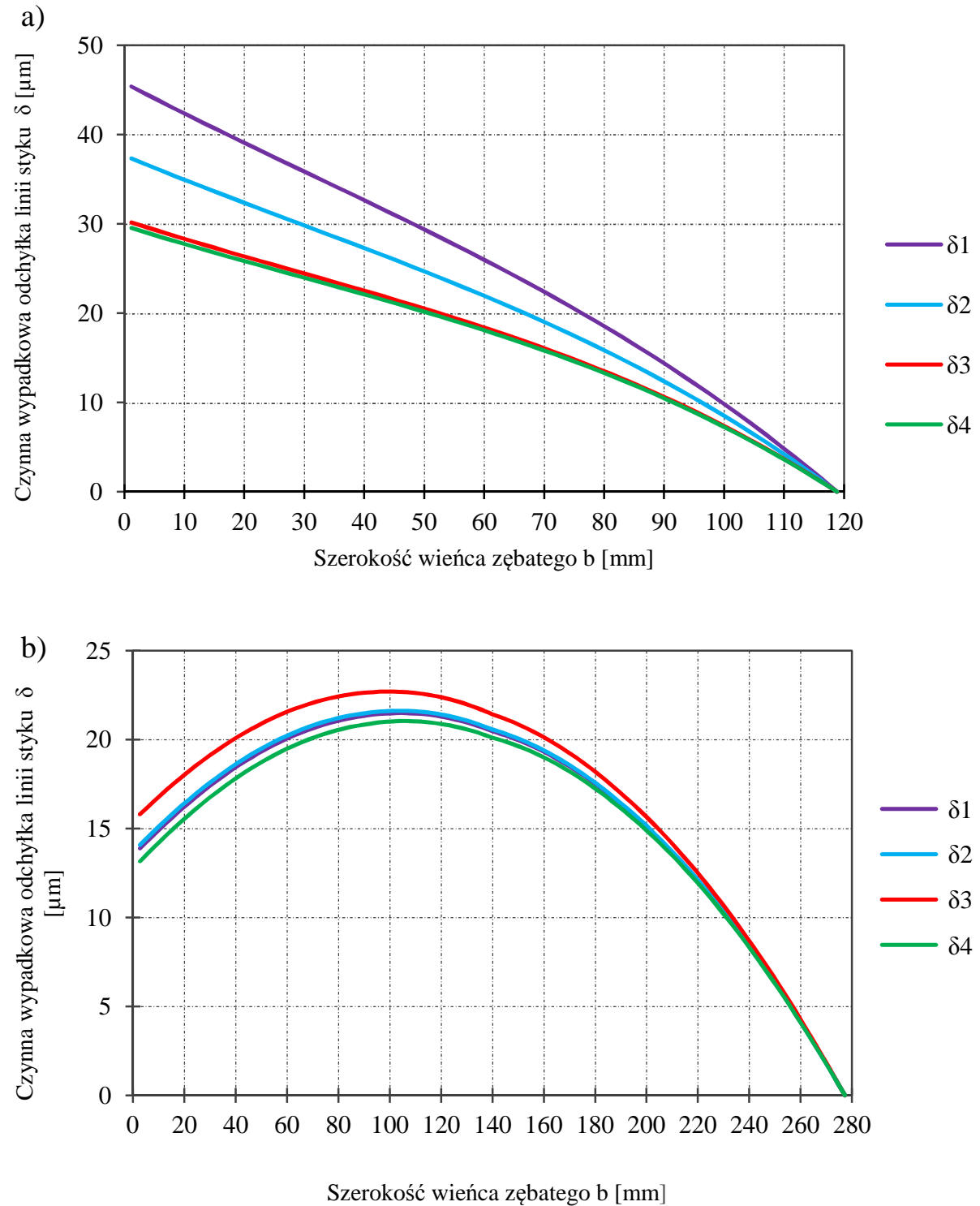

Rys.6. Wypadkowa odchyłka linii styku pary zębatej: a) 37-59 stopnia pierwszego, b) 21-95 stopnia drugiego

Fig. 6. Resultant deviation of contact line of the gear pair: a) 37-59 of 1st stage, and b) 21-95 of 2nd stage

W tabeli 5 umieszczono obliczone wartości współczynników $\mathrm{K}_{\mathrm{H} \beta}$, dla poszczególnych analiz. Poza całkowitym współczynnikiem $K_{\mathrm{H} \beta}$ odpowiadającym sumarycznej odchyłce linii styku dwóch współpracujących kół zębatych, przed- 
stawiono wyniki w rozbiciu na dwa przypadki, gdzie zakłada się bezbłędne wykonanie i nieskończenie sztywny charakter członu współpracującego $\left(\mathrm{K}_{\mathrm{H} \beta \mathrm{x}}=1\right)$. Pozwala to na lepszą ocenę wpływu badanych wielkości na rozkład obciążenia pod kątem konstrukcji poszczególnych członów przekładni. Należy przy tym również zwrócić uwagę na różnicę w przełożeniu analizowanych par zębatych.

Tabela 5. Wartości współczynnika $\mathrm{K}_{\mathrm{H} \beta}$ dla wykonanych analiz

Table 5. The values of the $K_{H \beta}$ factor for conducted analyses

\begin{tabular}{|c|c|c|c|c|c|c|}
\hline & \multicolumn{3}{|c|}{ Stopień pierwszy (37-59) } & \multicolumn{3}{c|}{ Stopień drugi (21-95) } \\
\hline Analiza nr & $\mathrm{K}_{\mathrm{H} \beta}$ & $\mathrm{K}_{\mathrm{H} \beta \text {-zębnik }}$ & $\mathrm{K}_{\mathrm{H} \beta \text {-koło }}$ & $\mathrm{K}_{\mathrm{H} \beta}$ & $\mathrm{K}_{\mathrm{H} \beta \text {-zębnik }}$ & $\mathrm{K}_{\mathrm{H} \beta \text {-koło }}$ \\
\hline 1 & 1,4900 & 1,1316 & 1,3584 & 1,2603 & 1,3698 & 1,0747 \\
\hline 2 & 1,4106 & 1,1175 & 1,2930 & 1,2620 & 1,3706 & 1,0738 \\
\hline 3 & 1,3402 & 1,0255 & 1,3509 & 1,2762 & 1,4187 & 1,1076 \\
\hline 4 & 1,3340 & 1,0135 & 1,3344 & 1,2543 & 1,4307 & 1,1417 \\
\hline
\end{tabular}

Na podstawie przeprowadzonych obliczeń i uzyskanych wyników można zauważyć:

- Znaczącą zmianę współczynnika $K_{\mathrm{H} \beta}$ dla pary zębatej stopnia pierwszego oraz zmianę kierunku odkształceń giętnych wału wejściowego w zakresie szerokości wieńca zębnika pod wpływem odkształceń sprężystych korpusu (krzywa f3). Charakter tych zmian został zachowany dla analizy 4.

- Wyraźnie mały wpływ rozpatrywanych czynników na współczynnik $K_{\mathrm{H} \beta}$ pary zębatej stopnia drugiego. Wykresy linii ugięcia wałów tej pary zębatej dla wszystkich czterech analiz wykazują ten sam charakter i kierunek ugięcia co decyduje o niewielkiej zmianie wypadkowej odchyłki linii styku.

- Widoczny wpływ zmiany luzu roboczego łożysk pod wpływem rozszerzalności cieplnej na rozkład obciążenia wzdłuż linii styku pary zębatej stopnia pierwszego.

- Mały wpływ odkształcalności cieplnej korpusu na zmianę współczynnika $\mathrm{K}_{\mathrm{H} \beta}$.

Przy ocenie uzyskanych wyników szczególną uwagę należy zwrócić na dużą zmianę wartości przemieszczeń wałów w łożyskach tj. zmianę luzu roboczego oraz przemieszczeń łożysk względem pozycji bazowej pod wpływem odkształceń sprężystych i cieplnych korpusu. W rozpatrywanym przypadku duże zmiany przemieszczeń nie skutkują równie dużymi zmianami wypadkowej odchyłki linii styku. Ponieważ przy wyznaczaniu współczynnika $K_{\mathrm{H} \beta}$ istotne znaczenie ma przebieg odkształceń wałów w zakresie szerokości wieńców kół zębatych a decydujący wpływ na jego charakter ma sztywność kół, wałów i systemu w jakim się znajdują to każdy przypadek należy rozpatrywać indywidualnie. Można podejrzewać, że w przypadku przekładni o mniejszej sztywności wałów, korpusów oraz większym rozstawie łożysk niż jest to dla badanego przypadku, wpływ zjawisk cieplnych mógłby być znacznie większy. 


\section{Podsumowanie}

Na podstawie uzyskanych wyników nie można sformułować uogólniających wniosków co do oceny wpływu rozszerzalności cieplnej członów przekładni zębatej na wypadkową odchyłkę linii styku, a co za tym idzie rozkładu obciążenia na powierzchni boku zęba. Dla pary zębatej stopnia pierwszego wpływ ten jest znaczący, zatem powinien być uwzględniony. Wyniki uzyskane dla pary zębatej stopnia drugiego charakteryzują się niewielką zmianą współczynnika $K_{\mathrm{H} \beta}$ przy jednocześnie dużych wartościach przemieszczeń wałów. Wszystko to świadczy o konieczności i zasadności wykonania przedstawionych analiz na etapie projektowania optymalnej modyfikacji linii zęba odpowiedzialnej przekładni zębatej. Odpowiednim narzędziem do oceny wpływu zjawisk zachodzących w przekładni na rozkład obciążenia wzdłuż linii styku jest metoda analityczna wbudowana w program komputerowy wspomagający prace inżynierskie.

\section{Literatura}

[1] AGMA 13FTM08: Application and Improvement of Face Load Factor Determination Based on AGMA 927.

[2] AGMA 2001-D04: Fundamental Rating Factors and Calculation Methods for Involute Spur and Helical Gear Teeth.

[3] AGMA 927-A01: Load Distribution Factors - Analytical Methods for Cylindrical Gears.

[4] DNV - Det Norske Veritas 41.2: Calculation of Gear Rating for Marine Transmissions.

[5] Gicala B.: Symulacja numeryczna rozkładu temperatury korpusu przekładni zębatej, Maszyny Górnicze, 29 (2011) 3-11.

[6] ISO/TR 14179-1:2001: Gears - Thermal capacity - Part 1: Rating gear drives with thermal equilibrium at $95{ }^{\circ} \mathrm{C}$ sump temperature.

[7] ISO/TR 14179-2:2001: Gears - Thermal capacity - Part 2: Thermal load-carrying capacity.

[8] ISO/TR 16281:2008: Rolling bearings - Methods for calculating the modified reference rating life for universally loaded bearings.

[9] ISO 6336-1:2006: Calculation of load capacity of spur and helical gears - Part 1: Basic principles, introduction and general influence factors.

[10]Jaśkiewicz Z., Wąsiewski A.: Przekładnie Walcowe. Geometria - Wytrzymałość Dokładność wykonania, WKŁ, Warszawa 1992.

[11]Łożyska Toczne. SKF 2014.

[12]Martinaglia L.: Thermal Behavior of High - Speed Gears and Tooth Corrections for Such Gears, ASME/AGMA International Symposium on Gears and Transmissions, San Francisco 1972.

[13]Rolling Bearings in industrial gearboxes. SKF 1997.

[14]Timken Engineering Manual. TIMKEN 2011. 


\section{EFFECT OF THERMAL EXPANSION ON NON-UNIFORMITY OF LOAD DISTRIBUTION ALONG THE CONTACT LINE}

\section{S u m m a ry}

This paper presents the results of numerical calculations of the effect of thermal expansion of housing and subassemblies of two stage cylindrical gear on the value of coefficient of load distribution non-uniformity along the contact line $\mathrm{K}_{\mathrm{H} \beta}$. An analysis was carried out for toothed gear that is a part of main power transmission system of marine power plant. An iterative method of evaluation of load distribution along the contact line described in ISO 6336-1, annex E was used. The usability of implementation of iterative method inside the CAE program environment and facility their evolution including the additional factors and phenomena which increase the computational accuracy is revealed. The achieved results allow to assess the effect of thermal expansion phenomenon and validity of their including on the stage of design of modification of flank pitch line of toothed gear of marine power plant.

Keywords: $\mathrm{K}_{\mathrm{H} \beta}$ coefficient, marine power plant, gear, deviation of contact line

DOI: $10.7862 / \mathrm{rm} .2017 .05$

Otrzymano/received: 4.02.2017

Zaakceptowano/accepted: 22.03.2017 